\title{
Perbedaan Durasi Tidur dan Asupan Makan pada Anak Stunting dan Tidak Stunting Usia Sekolah
}

\section{The Differences in Sleep Duration and Food Intake on The Incidence of Stunted Children at Elementary School}

\author{
Yessi Alza ${ }^{1}$, Lidya Novita ${ }^{2}$ \\ Jurusan Gizi, Politeknik Kesehatan Kemenkes Riau, Indonesia
}

\section{ARTICLE INFO}

\section{Article history}

Received date

08 Feb 2021

Revised date

07 Mar 2021

Accepted date

08 Apr 2021

\section{Keywords:}

Children;

Food intake;

Sleep duration;

Stunting.

\section{Kata kunci:}

Anak;

Asupan makan;

Durasi tidur;

Stunting.

\begin{abstract}
ABSTRAK
Stunting is a chronic malnutrition problem caused by inadequate nutritional intake for a long time, resulting in growth disorders in children that is height is lower than the standard age. The physical growth of children is greatly influenced by nutritional intake and activity in children. The purpose of this study was to determine the differences in sleep duration and food intake on the incidence of stunting in elementary school children. This was an analytic observational study with a cross-sectional design. This research was conducted in Kecamatan Tampan Sidomulyo Timur in February-August 2019. The sample of this study was 90 elementary school children who met the inclusion criteria. The independent variables in this study were sleep duration, food intake and the dependent variable was stunting. The data collection consists of weighing, height measurement, food recall $2 \times 24$ hours to determine the level of food consumption, and interviews by filling out a modified Children's Sleep Habit Questioner (CSHQ) questionnaire. Data analysis used an independent t-test and Mann-Whitney test. The results showed that there was no difference in sleep duration between stunting and nonstunting children $(p$-value $=0,954)$ and there was a difference in energy and protein intake between stunted and non-stunting children ( $p$-value $=0,004$ and $p$-value $=0,036)$. Children who have inadequate protein and energy have a greater risk of stunting. Further researchers need to test the difference in sleep duration between stunted and non-stunted children.
\end{abstract}

Stunting adalah masalah kurang gizi kronis yang disebabkan oleh kurangnya asupan gizi dalam waktu yang cukup lama, sehingga mengakibatkan gangguan pertumbuhan pada anak yakni tinggi badan anak lebih rendah atau pendek (kerdil) dari standar usianya. Pertumbuhan fisik anak sangat dipengaruhi oleh asupan nutrisi dan durasi tidur pada anak. Penelitian ini bertujuan untuk mengetahui perbedaan durasi tidur dan asupan makanan terhadap kejadian stunting pada anak usia sekolah dasar. Penelitian ini dilaksanakan dengan metode observasional analitik menggunakan desain cross sectional. Penelitian ini dilaksanakan di Kecamatan Tampan Sidomulyo Timur pada bulan FebuariAgustus 2019. Sampel penelitian ini sejumlah 90 anak usia sekolah yang memenuhi kriteria inklusi. Variabel bebas dalam penelitian ini adalah durasi tidur, asupan makanan dan variabel terikat adalah stunting. Pengumpulan data terdiri dari penimbangan berat badan, pengukuran tinggi badan, food recall $2 \times 24$ jam untuk mengetahui tingkat konsumsi makanan dan wawancara dengan mengisi kuesioner modifikasi Children's Sleep Habit Questioner (CSHQ) untuk mengetahui durasi tidur pada anak. Analisis data menggunakan independent $t$-test dan Uji Mann-Whitney. Hasil penelitian menunjukkan tidak terdapat perbedaan durasi tidur antara anak stunting dan tidak stunting ( $p$ value $=0,954$ ) dan terdapat perbedaan asupan energi dan protein antara anak stunting dan tidak stunting ( $p$-value $=0,004$ dan $p$-value $=0,036$ ). Anak yang memiliki tingkat kecukupan energi dan protein inadekuat memiliki risiko lebih besar untuk stunting. Perlu dilakukan penelitian lebih lanjut dengan melihat uji perbedaan durasi tidur antara anak yang stunting dengan anak tidak stunting

\footnotetext{
Corresponding Author:
}

Yessi Alza

Jurusan Gizi, Poltekkes Kemenkes Riau, Indonesia

Email: yessi@pkr.ac.id 


\section{PENDAHULUAN}

Masalah anak pendek (stunting) merupakan salah satu permasalahan yang dihadapi di dunia saat ini, khususnya di negaranegara miskin dan berkembang salah satunya Indonesia (Nurkarimah, et al., 2018). Stunting adalah masalah kurang gizi kronis yang disebabkan oleh kurangnya asupan gizi dalam waktu yang cukup lama, sehingga mengakibatkan gangguan pertumbuhan pada anak yakni tinggi badan anak lebih rendah atau pendek (kerdil) dari standar usianya (Izwardy, 2020). Stunting ditandai dengan nilai $z$-score tinggi badan menurut usia $(\mathrm{TB} / \mathrm{U})$ kurang dari -2 standar deviasi (SD) berdasarkan standar World Health Organization (WHO) (Nasikhah, 2012).

Kondisi stunting pada masa balita dapat menyebabkan gangguan perkembangan fungsi kognitif dan psikomotor serta penurunan produktivitas ketika dewasa (Nasikhah, 2012). Stunting dan masalah gizi lain diperkirakan menurunkan Produk Domestik Bruto (PDB) sekitar 3\% per tahun (TNP2K, 2018). Hasil Riskesdas tahun 2018 menunjukkan prevalensi stunting di tingkat nasional sebesar 30,8\% sedangkan di Provinsi Riau mencapai 27,3\%. Penelitian terdahulu menunjukkan bahwa $57,3 \%$ anak sekolah dasar yang berstatus gizi baik, tidak mengalami gangguan pertumbuhan. Sedangkan sisanya mengalami gangguan partumbuhan tingkat sedang (31,5\%) dan tingkat kurang 11,2\% (Kementerian Kesehatan RI, 2018; Sulastri, 2012).

Periode terpenting perkembangan dan pertumbuhan manusia adalah tahun-tahun pertama kehidupan (Wadood, 2017). Makanan yang dikonsumsi anak usia balita menentukan pertumbuhan dan perkembangan di masa yang akan datang. Kurangnya konsumsi zat gizi dapat menyebabkan beberapa masalah gizi, salah satunya yaitu stunting (Azmy dan Mundiastuti, 2018).

Anak SD yang berusia sekitar 7-13 tahun merupakan masa-masa pertumbuhan paling pesat kedua setelah masa balita. Anak usia sekolah memerlukan tambahan energi, protein, kalsium, fluor, zat besi karena pertumbuhan pada kisaran usia ini sedang pesat dan aktivitas anak semakin bertambah (Pritasari, et al., 2017). Tahun kedua kehidupan ini lebih memungkingkan anak menjadi kurus dan kerdil (Alza, et al., 2020).

Sama halnya dengan asupan makan dan aktivitas fisik, tidur juga memainkan peran penting dalam pematangan, pertumbuhan, dan kesehatan anak-anak dan remaja dengan memungkinkan ritme diurnal hormon yang terkait dengan pematangan, pertumbuhan dan homeostasis energi. Namun saat ini, tidur telah menerima perhatian yang jauh lebih sedikit daripada aktivitas fisik dan asupan makanan (Wadood, 2017).

Tidur merupakan aktifitas yang penting bagi manusia khususnya untuk anak-anak (Apriningtyas \& Kristini, 2019). Ketika anak tidur, pertumbuhan otak mencapai puncaknya begitu pula dengan otot, kulit, sistem jantung, pembuluh darah, metabolisme tubuh, dan tulang mengalami pertumbuhan pesat. Hal itu disebabkan tubuh anak-anak memproduksi hormon pertumbuhan tiga kali lebih banyak dibandingkan ketika dia terbangun. Salah satu hormon yang penting untuk pertumbuhan adalah Growth Hormon (GH) (Simanjuntak, et al., 2018).

Anak membutuhkan waktu 9 sampai 9,25 jam untuk tidur dalam sehari, namun faktanya hanya sekitar 8 jam sehari karena pengaruh waktu sekolah. Waktu tidur dan bangun berdasarkan waktu sekolah dan kehidupan sosial akan mempengaruhi pengurangan waktu tidur pada anak yang berdampak pada terjadinya gangguan tidur (Awwal, et al., 2015). Penelitian ini bertujuan untuk mengetahui perbedaan durasi tidur dan asupan makanan anak stunting dan tidak stunting pada usia sekolah dasar.

\section{METODE}

Penelitian ini dilaksanakan dengan metode observasional analitik menggunakan desain cross sectional. Penelitian ini dilaksanakan di Kecamatan Tampan Sidomulyo Timur pada bulan Febuari-Agustus 2019. Teknik pengambilan sampel dalam penelitian ini adalah dengan purposive sampling yakni dengan pengambilan seluruh populasi berdasarkan kriteria inklusi dan eksklusi sebesar 90 diambil seluruhnya sebagai sampel. Kriteria inklusi yaitu orang tua atau pengasuh menyetujui anaknya dilibatkan dalam penelitian dan bersedia menandatangani informed consent dan anak dapat berkomunikasi dengan baik. Kriteria eksklusi yaitu anak menderita penyakit berat kelainan kongenital (penyakit jantung bawaan), cacat fisik, dan infeksi kronis (TBC).Variabel bebas dalam penelitian ini adalah durasi tidur, asupan makanan dan variabel terikat adalah stunting.

Pengambilan data dilakukan selama 2 minggu. Pengukuran antropometri (berat dan tinggi badan) oleh enumerator yang telah dilatih sebelumnya, kemudian dikonversikan dalam bentuk z-score berdasarkan indeks TB/U (Tinggi Badan berdasarkan umur) sesuai dengan Keputusan Menteri Kesehatan RI 
No:1995/MENKES/SK/XII/2010 tentang Standar Antropometri Penilaian Status Gizi Anak. Selain itu, dilakukan food recall $2 \times 24$ jam untuk mengetahui tingkat konsumsi makanan dan wawancara dengan mengisi kuesioner modifikasi Children's Sleep Habit Questioner (CSHQ) untuk mengetahui durasi tidur pada anak (Kementerian Kesehatan RI, 2011). Izin penelitian dan kelaikan etik diperoleh dari Komite Etik Penelitian Kesehatan Politeknik Kesehatan Kemenkes Riau dengan nomor surat LB.02.03/6/23/2019.

Berdasarkan hasil uji normalitas, untuk data normal dilakukan perhitungan dengan independent $t$-test sedangkan untuk data yang tidak normal dilakukanperhitungan dengan Mann-Whitney Test. Analisa data menggunakan independent t-test untuk mengetahui hubungan stunting dengan asupan energi, protein, karbohidrat dan kalsium sedangkan Uji MannWhitney digunakan untuk mengetahui hubungan stunting dengan durasi tidur, asupan lemak dan zink.

\section{HASIL}

\section{Tabel 1. Karakteristik Responden Penelitian}

\begin{tabular}{lrr}
\hline Karakteristik & n & \% \\
\hline Jenis kelamin : & & \\
Laki-laki & 57 & 63.3 \\
Perempuan & 33 & 36.7 \\
Umur Responden : & & \\
7 Tahun & 29 & 32.2 \\
8 Tahun & 49 & 54.4 \\
9 Tahun & 11 & 12.2 \\
10 Tahun & 1 & 1.1 \\
Kejadian Stunting & & \\
$\quad$ Stunting & 11 & 12.2 \\
Tidak Stunting & 79 & 87.8 \\
\hline
\end{tabular}

Pada tabel 1 diketahui responden mayoritas berjenis kelamin laki-laki $(63,3 \%)$, dan berumur 7 tahun $(32,2 \%)$. Diketahui pula sebagian besar responden tidak mengalami stunting yaitu sebanyak 79 orang $(87,8 \%)$.

Tabel 2. Perbedaan Asupan Zat Gizi dan Durasi Tidur dengan Status Gizi (TB/U)

\begin{tabular}{lrrrrr}
\hline \multirow{2}{*}{ Variabel } & \multicolumn{1}{c}{ Stunting } & \multicolumn{3}{c}{ Tidak Stunting } & \multirow{2}{*}{ p-value } \\
\cline { 2 - 5 } & \multicolumn{1}{c}{ Rerata \pm SD } & \multicolumn{1}{c}{ SE } & \multicolumn{1}{c}{ Rerata \pm SD } & \multicolumn{1}{c}{ SE } & \\
\hline Asupan Energi (kkal) & $935,99 \pm 122,78$ & 37,02 & $1541,53 \pm 350,3$ & 39,4 & $0,004^{*}$ \\
Asupan Protein (g) & $32,2 \pm 4,1$ & 1,23 & $56,15 \pm 37,01$ & 4,16 & $0,036^{*}$ \\
Asupan Lemak (g) & $60,92 \pm 43.45$ & 13,1 & $59,02 \pm 30,65$ & 4,12 & $0,995^{* *}$ \\
Asupan Karbohidrat (g) & $215,97 \pm 74,22$ & 22,3 & $220,27 \pm 62,26$ & 7,01 & $0,954^{*}$ \\
Asupan Kalsium (mg) & $408,55 \pm 179,79$ & 54,21 & $460,49 \pm 200,45$ & 22,5 & $0,153^{*}$ \\
Asupan Zink (mg) & $14,38 \pm 40,89$ & 12,33 & $23,61 \pm 143,7$ & 16,17 & $0,704^{* *}$ \\
Durasi Tidur (jam) & $9,55 \pm 0,472$ & 0,142 & $9,49 \pm 1,05$ & 0,118 & $0,954^{* *}$ \\
\hline
\end{tabular}

Uji Independent T-test

${ }^{* *}$ Uji Mann-Whitney

Berdasarkan hasil pengukuran antropometri diperoleh $12,2 \%$ responden stunting dengan nilai rata-rata $z$-score $\mathrm{TB} / \mathrm{U}-2,46 \pm 0,52$ SD dan tidak stunting $-0,75 \pm 0,79$ SD. Berdasarkan status gizi, $81,1 \%$ responden tergolong memiliki status gizi normal dengan nilai rata-rata $z$-score IMT/U 0,05 $\pm 1,55 \mathrm{SD}$.

Analisis perbedaan asupan makanan (energi, protein, lemak dan kalsium) pada anak stunting dan tidak stunting dengan menggunakan independent $t$-test karena kedua variabel berskala rasio dan berdistribusi normal berdasarkan hasil uji normalitas One Sample KolmogorovSmirnovsedangkan data yang tidak berdistribusi normal menggunakan uji Mann-Whitney.

Analisis statistik menunjukkan ada perbedaan yang bermakna ( $p$-value $<0,05)$ antara asupan energi dan protein pada anak stunting dan anak tidak stunting. Data tersebut menunjukkan rerata asupan energi dan protein sebesar 935,9kkal dan 32,3g pada anak stunting dan rata- rata asupan energi dan protein sebesar $1541,5 \mathrm{kkal}$ dan 56,1g pada anak tidak stunting.

\section{PEMBAHASAN}

\section{Hubungan Durasi Tidur dengan Kejadian Stunting}

Sebuah teori menyatakan bahwa gangguan tidur dapat menyebabkan terjadinya perubahan hormonal pada tubuh, salah satunya adalah hormon pertumbuhan atau growth hormone (GH). GH dikeluarkan pada saat anak tidur, di mana GH ini tiga kali lebih banyak dibandingkan saat terbangun. Tingginya kadar GH ini erat hubungannya dengan kondisi fisik anak karena hormon ini mempunyai tugas merangsang pertumbuhan tulang dan jaringan, serta mengatur metabolisme tubuh. GH sangat berperan pada proses pertumbuhan anak, yakni sebagai stimulator pertumbuhan dan pembelahan sel di 
setiap bagian tubuh dan tulang rawan, meningkatkan proses mineralisasi tulang, meningkatkan sintesis protein tubuh, serta memacu insulin like growthfactor yang berfungsi pada pertumbuhan dan perkembangan sel tubuh (Zahara, et al., 2013).

Hasil penelitian ini berbeda dengan teori dan penelitian sebelumnya yang menyatakan bahwa terdapat hubungan antara gangguan tidur dan pertumbuhan pada anak. Pada penelitian ini, diketahui bahwa tidak ada perbedaan durasi tidur antara anak stunting dan tidak stunting ( $p$ value $=0,954)$. Rata-rata durasi tidur anak stunting dengan anak stunting tidak ada perbedaan yang signifikan. Anak usia sekolah membutuhkan waktu 9 sampai 9,25 jam untuk tidur dalam sehari.Berdasarkan hasil pengamatan dan wawancara dengan responden, pola tidur anak sebenarnya sudah cukup baik dan durasi tidurnya pun sudah cukup.Selain tidur di malam hari, anak juga memiliki jadwal tidur siang di Sekolah.

Beberapa survei juga mengumpulkan hasil kesehatan seperti tinggi badan, berat badan, dan daftar masalah medis, berdasarkan laporan orang tua atau anak. Mengandalkan laporan ini mungkin menjadi sumber kesalahan pengukuran. Juga, ukuran durasi tidur sering tidak menangkap informasi tentang keteraturan pola tidur, waktu tidur, atau kualitas tidur, yang semuanya dapat secara langsung mempengaruhi durasi tidur dan hasil kesehatan (Paruthi, et al., 2016).

Penelitian lainnya, menunjukkan bahwa korelasi antara anak-anak dan remaja durasi tidur dan kualitas tidur rendah atau tidak signifikan (Liu \& Zhou, 2002).

\section{Hubungan Asupan Makan dengan Kejadian Stunting}

Berdasarkan hasil analisis diketahui bahwa terdapat perbedaan antara asupan energi anak stunting dan anak tidak stunting ( $p$-value $=0,004)$. Rata-rata asupan energi anak stunting $935.9 \mathrm{kkal}$ (56.7\% AKG) dan rata-rata asupan energi anak tidak stunting1541,5 kkal (93,5\% AKG). Anak dengan tingkat asupan energi yang rendah mempengaruhi fungsi dan struktural perkembangan otak serta dapat mengakibatkan pertumbuhan dan perkembangan kognitif yang terhambat. Energi memiliki fungsi sebagai penunjang proses pertumbuhan, metabolisme tubuh dan berperan dalam proses aktivitas fisik (Setiawati, et al., 2020).

Berdasarkan penelitian yang dilakukan (Oktarina \& Sudiarti, 2013) menunjukkan bahwa balita yang memiliki asupan energi rendah berisiko stunting. Energi dalam tubuh manusia timbul karena adanya pembakaran dari karbohidrat, protein, dan lemak. Oleh karena itu, dibutuhkan adanya zat makanan yang dapat mencukupi kebutuhan tubuh dari seseorang tersebut. Hal ini menunjukkan bahwa semakin baik konsumsi energi pada balita maka semakin baik status gizinya (Watson, et al., 2015).

Hasil penelitian juga menunjukkan bahwa asupan protein anak stunting lebih rendah dibandingkan anak tidak stunting, dengan ratarata konsumsi 32,3g/hari pada anak stunting dan $56,1 \mathrm{~g} /$ hari pada anak tidak stunting. Berdasarkan hasil analisis diketahui bahwa terdapat perbedaan antara asupan protein anak stunting dan anak tidak stunting ( $p$-value $=0,036)$. Penelitian ini sejalan dengan penelitian yang dilakukan oleh Azmy dan Mundiastuti (2018) dimana terdapat hubungan antara tingkat konsumsi protein dengan stunting pada anak.

Asupan protein menyediakan asam amino yang diperlukan tubuh untuk membangun matriks tulang dan mempengaruhi pertumbuhan tulang karena protein berfungsi untuk memodifikasi sekresi dan aksi osteotropic hormone IGF-I, sehingga, asupan protein dapat memodulasi potensi genetik dari pencapaian peak bone mass. Asupan protein rendah terbukti merusak akuisisi mineral massa tulang dengan merusak produksi dan efek IGF-I. IGF-I mempengaruhi pertumbuhan tulang dengan merangsang proliferasi dan diferensiasi kondrosit di lempeng epifisis pertumbuhan dan langsung mempengaruhi osteoblas. Selain itu, IGF-I meningkatkan konversi ginjal dari 25 hidroksivitamin D3 menjadi aktif hormon 1,25 dihidroksi-vitamin D3 dan dengan demikian memberikan kontribusi untuk peningkatan penyerapan kalsium dan fosfor di usus (Sari, et al., 2016; Sulistianingsih \& Yanti, 2015).

Penelitian sebelumnya juga menyebutkan bahwa asupan energi dan protein yang rendah berdampak pada meningkatnya resiko masalah gizi seperti kekurangan energi kronis dan kekurangan energi protein, selain pada balita dapat berdampak pada terhambatnya pertumbuhan dan perkembangan kognitifnya (Diniyyah \& Nindya, 2017). Hal ini sesuai kerangka teori UNICEF yang menyatakan konsumsi makanan tidak adekuat merupakan salah satu faktor yang dapat mengakibatkan stunting (UNICEF, 1998). Sebuah studi yang dilakukan oleh (Wang, et al., 2009) juga menunjukkan bahwa penyebab kejadian stunting di Cina adalah defisiensi energi dan protein yang telah berlangsung jangka panjang. 


\section{SIMPULAN}

Tidak terdapat perbedaan durasi tidur antara anak stunting dan tidak stunting, serta terdapat perbedaan asupan energi dan protein

\section{DAFTAR PUSTAKA}

Alza, Y., Arsil, Y., Marlina, Y., Novita, L., \& Agustin, N. D. (2020). Aktivitas Fisik, Durasi Penyakit Dan Kadar Gula Darah Pada Penderita Diabetes Mellitus (Dm) Tipe 2. Gizido, 12(1), 18-26.

Apriningtyas, V. N., \& Kristini, T. D. (2019). Faktor Prenatal yang Berhubungan dengan Kejadian Stunting Anak Usia 6-24 Bulan. Jurnal Kesehatan Masyarakat Indonesia, 14(2), 13-17.

Awwal, H., Hartanto, F., \& Hendrianingtyas, M. (2015). Prevalensi Gangguan Tidur pada Remaja Usia 12-15 Tahun: Studi pada Siswa SMPN 5 Semarang. Jurnal Kedokteran Diponegoro, 4(4), 327-335.

Azmy, U., \& Mundiastuti, L. (2018). Konsumsi Zat Gizi pada Balita Stunting dan NonStunting di Kabupaten Bangkalan. Amerta Nutrition, 2(3), 292-298. https://doi.org/10.20473/amnt.v2.i3.2018.29 2-298

Diniyyah, S. R., \& Nindya, T. S. (2017). Asupan Energi, Protein dan Lemak dengan Kejadian Gizi Kurang pada Balita Usia 2459 Bulan di Desa Suci , Gresik. Amerta Nutrition, 1(4), 341-350. https://doi.org/10.20473/amnt.v1.i4.2017.34 $1-350$

Izwardy, D. (2020). Studi Status Gizi Balita Terintegrasi Susenas 2019. Balitbangkes Kemenkes RI. Kementerian Kesehatan Republik Indonesia.

Kementerian Kesehatan RI. (2011). Keputusan Menteri Kesehatan RI No:1995/MENKES/SK/XII/2010 tentang Standar Antropometri Penilaian Status Gizi Anak, (2011).

Kementerian Kesehatan RI. (2018). Riset Kesehatan Dasar (Riskesdas) Tahun 2018. Kementerian Kesehatan Republik Indonesia.

Liu, X., \& Zhou, H. (2002). Sleep duration, insomnia and behavioral problems among Chinese adolescents. Psychiatry Research, $111(1)$, 75-85. https://doi.org/10.1016/S01651781(02)00131-2

Nasikhah, R. (2012). Faktor Risiko Kejadian antara anak stunting dan tidak stunting. Anak yang memiliki tingkat kecukupan energi dan protein inadekuat memiliki risiko lebih besar untuk stunting.

Stunting Pada Balita Usia 24-36 Bulan Di Kecamatan Semarang Timur. [Skripsi]. Semarang: Fakultas Kedokteran, Universitas Diponegoro.

Nurkarimah, Hasanah, O., \& Bayhakki. (2018). Hubungan Durasi Pemberian ASI Ekslusif Dengan Kejadian Stunting Pada Anak. JOM FKp, 5(2), 184-192. jom.unri.ac.id

Oktarina, Z., \& Sudiarti, T. (2013). Faktor Risiko Stunting Pada Balita (24-59 Bulan) Di Sumatera. Jurnal Gizi Dan Pangan, 8(3), 175-180.

Paruthi, S., Brooks, L. J., D’Ambrosio, C., Hall, W. A., Kotagal, S., Lloyd, R. M., Malow, B. A., Maski, K., Nichols, C., Quan, S. F., Rosen, C. L., Troester, M. M., \& Wise, M. S. (2016). Consensus Statement of the American Academy of Sleep Medicine on the Recommended Amount of Sleep for Healthy Children: Methodology and Discussion. Journal of Clinical Sleep Medicine, 12(11), 1549-1561. https://doi.org/10.5664/jcsm.6288

Pritasari, Damayanti, D., \& Nugraheni, T. L. (2017). Gizi Dalam Daur Kehidupan. Kementerian Kesehatan Republik Indonesia.

Sari, E. M., Juffriie, M., Nurani, N., \& Sitaresmi, M. N. (2016). Asupan Protein, Kalsium dan Fosfor Pada Anak Stunting dan Tidak Stunting Usia 24-59 Bulan. Jurnal Gizi Klinik Indonesia, 12(4), 152-159.

Setiawati, S., Yani, E. R., \& Rachmawati, M. (2020). Hubungan status gizi dengan pertumbuhan dan perkembangan balita 1-3 tahun. Holistik Jurnal Kesehatan, 14(1), 8895. https://doi.org/10.33024/hjk.v14i1.1903

Simanjuntak, J. H. A., Herlina, \& Bayhakki. (2018). Hubungan Kualitas Tidur Terhadap Terjadinya Wasting pada Anak Usia Sekolah. Jurnal Online Mahasiswa. Edisi Januari-Juni 2018, Vol 5.

Sulastri, D. (2012). Faktor Determinan Kejadian Stunting Pada Anak Usia Sekolah Di Kecamatan Lubuk Kilangan Kota Padang. Majalah Kedokteran Andalas, 36(1), 39-50.

Sulistianingsih, A., \& Yanti, D. A. M. (2015). Kurangnya Asupan Makan Sebagai 
Penyebab Kejadian Balita Pendek (Stunting). Jurnal Dunia Kesehatan, 5(1), 71-75.

TNP2K. (2018). Strategi Nasional Percepatan Pencegahan Anak Kerdil (Stunting). Kementerian Koordinator Bidang Pembangunan Manusia dan Kebudayaan.

United Nation International Children's Emergency Fund (UNICEF). (1998). The State of the World's Children. Focus on Nutrition.

Wadood, M. O. A. (2017). The Effect of Sleep Duration on Salivary Growth Hormone and Dental Occlusion in Relation to Height Status among Kindergarten Children. International Journal of Science and Research (IJSR), 6(4), 1350-1355. https://doi.org/10.21275/ART20172530

Wang, X., Höjer, B., Guo, S., Luo, S., Zhou, W., \& Wang, Y. (2009). Stunting and Overweight in the WHO Child Growth Standard: Malnutrition among Children in
Poor Area of China. Public Health Nutrition, 12(11), 1991-1998. https://doi.org/10.1017/S1368980009990796

Watson, N. F., Badr, M. S., Belenky, G., Bliwise, D. L., Buxton, O. M., Buysse, D., Dinges, D. F., Gangwisch, J., Grandner, M. A., Kushida, C., Malhotra, R. K., Martin, J. L., Patel, S. R., Quan, S. F., Tasali, E., Twery, M., Croft, J. B., Maher, E., Barrett, J. A., ... Heald, J. L. (2015). Joint Consensus Statement of the American Academy of Sleep Medicine and Sleep Research Society on the Recommended Amount of Sleep for a Healthy Adult: Methodology and Discussion. Journal of Clinical Sleep Medicine, 11(8), 931-952. https://doi.org/10.5664/jcsm.4950

Zahara, D. S., Hartanto, F., \& Adyaksa, G. (2013). Hubungan Antara Gangguan Tidur dengan Pertumbuhan Pada Anak Usia 3-6 Tahun Di Kota Semarang. Jurnal Kedokteran Diponegoro, 2(1), 109498. 